\title{
China and Cambodia Iron-Clad Relations: A Case Study of the Impact of China's Official Development Finance, Economic Infrastructure Developments on Cambodia's Exponential Economic Growth from 2010 to 2019
}

\author{
Rortha Chum \\ Techo Sen School of Government and International Relations, The University of Cambodia, Phnom Penh, Cambodia \\ Email: chumrortha@gmail.com
}

How to cite this paper: Chum, R. (2021) China and Cambodia Iron-Clad Relations: A Case Study of the Impact of China's Official Development Finance, Economic Infrastructure Developments on Cambodia's Exponential Economic Growth from 2010 to 2019. Open Access Library Journal, 8: e7330 https://doi.org/10.4236/oalib.1107330

Received: March 19, 2021

Accepted: April 26, 2021

Published: April 29, 2021

Copyright $\odot 2021$ by author(s) and Open Access Library Inc.

This work is licensed under the Creative Commons Attribution International License (CC BY 4.0).

http://creativecommons.org/licenses/by/4.0/

\begin{abstract}
Cambodia is one of the oldest and the most trusted of China's alliance. Chinese foreign assistance has influenced in interests of politics, strategics and economics. This article seeks to explore the close interaction of China's foreign financial aid influences and contributions in respect to economic infrastructure development on economic growth. Methods: Using in-depth interviews with twelve key experts' participants are conducted and transcribed by the author. The data analysis is employed thematic analysis and using Nvivo 10 are used to analysis, all interviews are transcribed by the author number of codes in systematic way by reducing data from the codes and then develop themes from the codes. Results: Chinese foreign assistance in respect to economic infrastructure development has increased contributions to economic interests and economic growth in short run and long run in Cambodia. Chinese foreign assistance to Cambodia contributes to mutual complementary interests in economic prosperity and on economic growth. Conclusions: Chinese foreign assistance has positive contributions to economic growth, despite 20 percent of participants are concerned over Chinese financial assistance on some low quality of economic infrastructure development.
\end{abstract}

\section{Subject Areas}

International Relations

\section{Keywords}

China's Official Development Finance, 
Chinese Financial Development Assistance,

Economic Infrastructure Development, Economic Interests, Economic Growth

\section{Introduction}

All economic and social infrastructures were an indispensable foundation of socio-economic development. Long term of civil wars was rendered and left Cambodia with ruined physical infrastructure as roads, irrigation systems and bridges. Most roads and bridges were being built and many of them funded via Chinese financial development assistance. China actually has been funding variety of development projects throughout Cambodia. Chinese investment in Cambodian infrastructure has been substantial. For example, Chinese firms have reportedly invested more than $\$ 1.6$ billion to build six dams in the kingdom (Open Development Cambodia, 8 December 2015) [1].

Generally, China helped a lot of construction of roads, bridges and electricity. According to Dr. Mey is a senior adviser to the Cambodia government's Supreme National Economic Council stressed and averred that without financial assistance from China, Cambodia may encounter so many issues [2].

Infrastructures, China has scaled up its military aid for improving capacity military, infrastructure, and material for modernization. China and Cambodia military have been to the level cooperation of joining military exercises in many times and used real weapons and Beijing promised new military aid. Chinese foreign aid is often undermined and categorized as rouge aid that guided by receipt need and the aid has driven China's interest alone. This article is to explore Chinese foreign aid is often complicated. Foreign aid has influenced on economic development and economic growth. Foreign development aid has played roles as pros and cons of economic development among nations. There has an extensive literature review on distribution of foreign aid by Western aid donors were emphasized on development aid was often financed for political purposes rather than economic reasons [3] [4] [5] [6].

The purpose of this study is to assess and analyses Chinese foreign assistance contribution on economic growth in respect to economic infrastructure development (roads, bridges, irrigation systems, and other physical infrastructures) on economic growth. In overall, to assess and analyses China's foreign assistance has positively contributed to economic growth in Cambodia. For this study is considered to assess Chinese foreign assistance and economic growth from 2010 to 2019 as Cambodia and China were signed as a Comprehensive Strategic Cooperative Partnership.

This research article seeks to analyses the gaps how has Chinese foreign aid in respect to economic infrastructure development contributed to economic growth in Cambodia. In addition, some policy recommendations will be advanced in order for Cambodia to seek a well-balanced position in conducting 
foreign policy and to catch the most national interests in the clad-iron relations between Cambodia and China. Limitation of this study is in concepts of China's foreign aid in infrastructure development and economic growth.

This paper is uniquely contributed to exiting discussion on Chinese foreign assistance in respect to economic infrastructure development contributions to economic growth in Cambodia. Given China's aid and controversies involvements have evoked in Cambodia, some key questions are being asked: How has Chinese foreign aid in respect to economic infrastructure development contributed to economic growth in Cambodia?" The rest of this paper is structured as follows. Section covers a related literature review, and then on section of main findings, section of discussion on the results and conclusion and recommendations.

\section{Related Literature Review}

\subsection{Defining Foreign Aid}

Foreign aid was defined as a public transferring fund among countries which were referred to a tool of foreign policy. Foreign aid was also two approaches, bilateral aid, multilateral aid, to non-governmental aid, technical aid was involved. In other, foreign aid was called as an "official development assistance (ODA)" which defined by the DAC of OECD as "concessional funding given to developing countries and to multilateral institutions, and provided by official agencies". As funding should be met the two main objectives: administration on the promotion of the economic improvement and welfare of developing recipient countries, and other is concessional character and contains a grant element at least twenty five percent (Sun, 2014; Br as cited in [7]. Chinese foreign assistance moved in a positive direction without abandoning its defining characteristics [8]. This study is used terms of interchanges of Chinese foreign assistance, Chinese foreign aid, China financial aid, China financial development and China aid.

\subsection{Dependency Theory}

Cambodia and China are dependent on each other since early the beginning of Cold War up to present. Cambodia was a compliant alliance of China ever since it was clear that mutual benefits were existed. For China, any nation-state that actively further the Chinese regional strategic agenda welcomed as a friend. Evidently, China's potential utility in shaping its ally's economy was argued that China should continue to play a vital role in Cambodia. Through a study was covered an array of scholarly and media sources. The article was attempted to elucidate some of the Sino-Cambodian linkages and the mutual interests were linked. And then the paper was revealed a brief account of the historical binding between the two countries. An analysis of the mechanisms, motivations, and subsidiary actions were designed to solidify strategic interests, and the potential consequences of such actions [9]. 
In early foreign aid, the history of modern foreign aid and colonialism were in many ways intertwined. Infrastructures were built under British rule were to transport primary commodities in southern and eastern Africa [10]. Main objectives and priorities of China's assistance were dependent on different regions. The level of its support of different states was varied across issue areas. It was primarily driven by its changing economic interest. In the long term interests, Cambodia were developed economic infrastructures were required to sustain inclusive commerce and all forms of inclusive development, inflows of aid can promote economic growth [10] [11] [12]. Transferring the use of new and advanced technology in building the new infrastructure of Cambodia that are facilitating and increasing and economic infrastructure have contributed to economic growth by increasing domestic investment [13] [14] [15].

China has been the strongest supporter for developing infrastructure such as roads, bridges, and public buildings, without attaching conditions. It is however important to note that it is in China's national interests and Cambodia's economic development and development assistance with commercial investment and trade managements [16] [17] [18]. The level of foreign support is primarily driven by its changing economic interest and aid on primary education has positive and significant on economic growth [19] [20] [21].

But the finding does not depend on assumptions about the functional form of the aid-growth relationship, does not arise from a handful of influential observations and is not an object of mean reversion [22]. Financial aid to poor democratic recipient countries is led to better economic growth and increasing capital inflows [23] [24].

Foreign aid is more effective improving economic growth and good governance [25]. The results were claimed that non-technical assistance has no statistically significant impact on growth; but technical assistance has a positive and significant impact, except in countries where it is highly fragmented [26] [27]. Bilateral aid is concluded to negative conclusion on economic growth [28]. Chinese foreign aid and economic growth, traditionally, most of foreign aid efforts seem to be designed mainly to scale up economic growth in receipt countries. However, there is no positive correlation between foreign aid and economic growth. Economic development as major goals for foreign aid has resulted mainly donor countries less explicit specified to their political motivation rather than economic objectives (Lin 1993). [29] these results are variable that it is undecided it is increase or decrease of foreign aid on economic growth [30]. The results of foreign aid and economic growth are inversely related while domestic savings seem to have been supplemented by aid [31] [32] [33].

The article also found that any technology has transferred in the dam and power grids of economic infrastructures were required to meet the real of strategic position in needs of going beyond hardware and focusing more on the transferring of expertise, skills and knowledge to enabling short term and long term sustainable development [34]. Chinese foreign aid to Cambodia, Cambodia 
was decided to develop highly in needed and demanded infrastructures are included roads, bridges, irrigation systems, and power grids [35].

China economic assistance to Cambodia has not only promote economic development but social development as well. China economic assistance has been made in many forms. These economic assistances are offered through grants, loans, concessional loans and free interest loans. These short of loans are aimed at building economic infrastructures such as roads, bridges, railways, seaports. This has been claimed repeatedly by Prime Minister Hun Sen China aid has a huge contribution to economic growth in Cambodia [36].

Aid-financed-government in public goods were included public infrastructures, education and health had a fundamental way through in which foreign aid was contributed to achieve largely development impacts and outcomes and in the long run whether it was success or failure was depended on capacity of institution to overcome challenges [37]. China has offered aid to Africa in social and economic development [38]. The results of empirical study indicated that China's foreign aid on infrastructure aid can effectively promote economic growth in recipient countries [39]. South Asia has been an important destination of foreign aid over the past decades. Economic infrastructure development in South Asian countries and the volume of aid has tremendously increased in recent years [40].

\section{Method}

This study used the qualitative method as in-depth interviews [41] [42]. The study defined purposeful sampling was a technique widely used in qualitative research for identification and selection information rich cases for most use of limited resources [43] and where I conducted interviews with 12 key experts' participants. The sampling was comprehensively consulted with my with dissertation supervisors and selected to seek for interviewing with targeted selected participants who are researchers, head of lecturers and policy makers with most relevant expertise dealing with foreign aid, foreign development assistance and particular, Chinese foreign aid from public and non-public sectors while 2 of respondents were not to reach to interview because an endorsement letter was required to reach to hand of the top decision makers, Covid-19 spike and the topic is a bit sensitive. Each participant was conducted in face-to-face interviews and about 40 minutes for a participant that it is supported by the researcher was required to build confidence and rapport and generates rich data. The schedule of interviews was required the study used purposed sampling technique and length of interviewed last about 30 - 60 minutes [44].

This analysis is employed thematic analysis in which counts number of codes in systematic way by reducing data from the codes and then develop themes from the codes. And it was using Nvivo 10 for analysis for an extensive literature review on China's foreign aid on economic growth. The interviews are conducted with experts from relevant government officials, UN's agencies and Re- 
search Institutes as well as Universities' lecturers and thus represent the perspective of different stakeholders. Unfortunately, the author was requested for interviews but 2 of participants were declined to participate. The interviews were conducted in Cambodia and then translated by myself.

\section{Main Findings}

China aid or financial assistance as grant in infrastructure's development were included bridges, roads, and agricultural infrastructures, schools, hospitals, scholarship and vehicles' gift for civil and military using such as grant in cars for national election committee and buses for public transportation and other grant for other social services as necessary materials and cash which provided interests to Cambodia.

\subsection{China Financial Assistance on Physical Infrastructure Development and Economic Growth}

The finding of this study is divided in to two kind of China aid on infrastructure development as concessional loans and grant. All participants were claimed that China aid as concessional loan on economic infrastructure developments have impacted in short term and long-term on economic growth in Cambodia. Less than 20 percent participants were claimed that China aid as grant made in a form of state to state and some donated by Chinese private donors. 83 percent of participants were stated that China aid as grant to Cambodia for development government's infrastructures are included friendship's buildings (Senate, Parliamentary, Council Ministers, schools, hospitals), friendship's bridges, roads' friendship, humanitarian relief, deb-relief, scholarship and technical assistance and natural disasters. But for humanitarian assistance as food relief and materials are impacted in short term relief and little impact in economic growth. All participants were claimed that China grant as physical infrastructures has been impacted in short term and long term on economic growth.

\subsection{China's Financial Assistance as Soft Loan for Civil and Military Infrastructure Development}

83 percent of participants were claimed that China financial assistance is called soft loan or concessional loan has offered to develop economic infrastructure. China soft loan or concessional loan offered with grace period which has charged in low interest rate for development major economic infrastructures in developing country such as roads, bridges, buildings, irrigation systems and railway and cultural infrastructures and social service structures. These short of Chinese financial assistances have contributed in short term and long-term economic development and economic growth. In other form of infrastructure development, almost 20 percent of participants were also claimed that China offered loan for military strategic infrastructure development along the border for military mobilities for national defense. China offered loans to Cambodia to 
build many strategic military infrastructures as belt roads and bridges along bordering parts and were built by Cambodian military engineering unit of Cambodian national defense.

Some participants were averred that interests of all short of infrastructures were built across major rivers for increasing and improving connection transportation and trade of the capital city to different cities and remote regions of the country as whole. These infrastructures are connected and encouraged frequencies for transportation from side-to-side connection between people to people for regular trading and services. These loans were offered to develop all infrastructures have positive impacted on increasing transportation activities, increasing trading, improving economic development and increasing economic growth in Cambodia.

All of participants were averred that China soft loans or concessional loans were lent to Cambodia to develop and to expand all economic infrastructures such as roads, bridges, railways for improving on compulsory economic sectors. These loans brought about accessibility of using infrastructure by all stakeholders that led economic development and economic growth.

Almost 20 percent participants were claimed Cambodian military aid from China in this way, Cambodia needs money to buy, for instance, military clothes and materials, inside and outside of Cambodia. There are two types of civil infrastructures. One is the sort of civil infrastructure that people use daily and two is called military infrastructure which is built by military engineering unit. These roads for military travelling and these roads are being developed by Cambodian Military Construction of Ministry of National Defense, especially roads along bordering belts.

"If military uses this aid or money to buy goods from China what will impact to economic in Cambodia. It is linked to import and export but it is less than military use money of China aid to buy some local materials so companies in domestic supply more to military demand that leads economic growth" [M8, male, CDRI].

"Aid to flood relief, it is an immediate impact to people. Some shorts of aid offer to build infrastructures, bridges, roads, buildings and energy sectors. In short, China aid has impacted short term on economic growth. [M4, male, Cambodian Institute Cooperation and Peace" (CICP)].

83 percent of participants were claimed China aid as gifts in some short of infrastructures were built for friendship and strengthening bilateral relationship have impact but it is insignificant on economic growth.

This study, China aid was relevant with capability of absorbing skills and knowledge transferring Chinese expert. Overall, China aid has positive impact on economic growth. First, China grant on capacity building has impacted on long term economic growth. In fact, these series of trainings are led to increase national productivity. Second, China grant on capacity building has impacted on long term economic growth but it is political effects for supporting to China. [...]. In fact, China has led study tours for those who get training in China to visit drone development and drone testing center and at that situation makes the 
participants were surprised on how China technology, capability for advancing technology and science [M9, male, Royal Academy of Cambodia (RAC)].

Some participants were argued some infrastructures were built for friendship and strengthening bilateral relationship. Overall, China aid has positive impact on economic growth.

In addition, foreign aid or China aid has impacted long term on economic growth. For example, humanitarian relief, aid is an emergent realized. Aid to flood relief, it is fast affect to people. Some shorts of aid offer to build infrastructure, bridges, roads and energy sectors. And then it has positive growth. But it is hard to measure unless it is applied econometric tool [M4, male, Cambodian Institute Cooperation and Peace (CICP)].

The economic infrastructure has positive impacted in short term and long term on economic growth but it has to prepare to absorbing capacity [M9, male, Royal Academy of Cambodia (RAC)].

The finding claims to China aid in form of infrastructures' development to Cambodia makes Cambodian is industrious and productive workers. China aid is a crucial capital input through concessional loan that weights and sustains economic growth about 7 percent per year.

For long term, Cambodian can get job and can get some indirect benefits. And sometimes, people can get direct benefits such as job creation, income. [...]. Over the last two decades, it is not only agricultural and industrial sectors but all sectors. All these sectors are added together, Cambodia gets 7 percent on economic growth [M3, male, Oxford Policy Management (OPM)].

Findings of this study supports that China aid has in-directed contribution to long term economic growth. China aid via China aid as grant for capacity development, humanitarian relief, and other infrastructures, power grids and economic health for national development to Cambodia. Economic diplomacy, economic infrastructure and social infrastructure financial assistance are built and strengthening bilateral friendship. In fact, China's foreign aid has big contribution to Cambodia economic growth through China financial assistance all economic infrastructures that Cambodia is highly demanded. China aid has impacted on FDI's total production factors and contributed to economic growth.

\subsection{Chinese Foreign Assistance Has Directed Impacts on SDG and Economic Growth}

83 percent of participants were claimed that all forms of China aid have contributed to national sustainable development goals and economic interests in short term and long-term economic growth through economic infrastructures, increasing real estate development, increasing transportation frequencies and cost cutting of transportation of goods, increasing trade activities, improving irrigation system for agricultural productivities and expanding power grids.

"Cambodian economic growth has increased more than 7 percent annually. I believe that there bilateral and multilateral aid. Aid offers to Cambodia by World 
Bank. I believe that China aid has contributed to 7 percent of annual economic growth. Many sectors of economy are agricultures, industries, and services. Recently, what I have seen is productions. 83 percent of China aid is offered to bridges, roads" [M3, male, Oxford Policy Management (OPM)].

China grant as form of developing infrastructures has been impacted in short term economic growth and long term on economic growth. China aid as grant in humanitarian and natural disaster have insignificant impact in economic growth. China grant in training as technical assistance in human resource development has brought about increasing skills and knowledge, increasing competencies in institutional, national productivity's outputs that contributed to all short of economic activities in short term and long term on economic growth.

The main findings of the study of Chinese foreign aid or China financial assistance is offered to major two categories: grant and soft loan or concessional loan. Majority of Chinese foreign aid is loan for development physical economic infrastructures while the rest is China grant for some social infrastructures as buildings and stadium, scholarship, human resource development, technical assistance, humanitarian assistance, agricultural assistance, health and national defense.

It is evidences that can be seen in Table 1 both China grant and China concessional loan in respect to all infrastructure developments has contributed directed, in-directed, short run and long run on economic growth. China aid has a positive impact in economic growth.

As an evidence can be seen China aid foreign aid has contributed to economic growth because in the word frequency, the word "economic" and the "growth" are seen significant than some other words. In Table 1, the word "economic" is ranked in $5^{\text {th }}$ of the top $1000^{\text {th }}$ word. Economic is counted 209 words. It is represented $1.65 \%$. In the similar meanings see that from Table 1 "economic, economically, economics, save, saves, saving, savings". In addition, the word "growth" is ranked $8^{\text {th }}$ of the top $1000^{\text {th }}$ word. Growth is accounted for $1.50 \%$. These mean that China aid is bring about development, emergence, growing, growth, increased, increases, increasing, incremental, maturity. In similar meanings from Table 1 indicates that "develop, developed, developers, developing, development, developments, develops, emerged, emergent, growing, growth, increase, increased, increases, increasing, incremental, maturity". In Table 1 is indicated the key high frequency word is Infrastructure, it was ranked in the top $20^{\text {th }}$ and it has 93 times that was mentioned by participants as percentage weighted was $0.70 \%$.

It has been seen cleared that from the results of analysis in the word cloud from NVivo 10 analysis. In addition, in Figure 1 is about the word clouds, the words that can be seen from 83 percent of comments and correlations is followed by and up to the least comments and correlations. The words include China, Cambodia, aid, infrastructure, economic and growth and then many other words. This reveals significant correlations of China aid impacts on economic growth. 
Table 1. Word frequency query is selected words from 1000 out of 16871 words

\begin{tabular}{|c|c|c|c|c|}
\hline Number & Word & Count & Weighed percentage $\%$ & Similar meanings \\
\hline 1 & china & 621 & 5.45 & china, chinas, prc, Taiwan \\
\hline 2 & aid & 429 & 3.45 & $\begin{array}{l}\text { aid, aided, aids, assist, assistance, assistances, assisted, assists, care, } \\
\text { cared, careful, help, helps, tend, tended, tends }\end{array}$ \\
\hline 3 & Cambodia & 362 & 3.18 & Cambodia \\
\hline 4 & government & 243 & 1.65 & $\begin{array}{l}\text { administration, administrative, authority, authors, control, controlled, } \\
\text { governance, governing, government, governments, order, organization, } \\
\text { organizations, political, politically, politics, regime, regular, rule }\end{array}$ \\
\hline 5 & economic & 209 & 1.65 & $\begin{array}{l}\text { economic, economically, economics, save, } \\
\text { saves, saving, savings }\end{array}$ \\
\hline 6 & countries & 232 & 1.56 & $\begin{array}{c}\text { area, areas, countries, countries', country, land, landing, nation, } \\
\text { national, nations, state, states }\end{array}$ \\
\hline 7 & need & 267 & 1.52 & $\begin{array}{l}\text { ask, asked, asking, asks, demand, demanded, demands, involved, } \\
\text { involving, motives, need, needs, require, required, requirement, } \\
\text { requirements, requires, take, takes, taking, want, wanted, wants }\end{array}$ \\
\hline 8 & growth & 255 & 1.50 & $\begin{array}{l}\text { develop, developed, developers, developing, development, developments, } \\
\text { develops, emerged, emergent, growing, growth, increase, increased, } \\
\text { increases, increasing, incremental, maturity }\end{array}$ \\
\hline 9 & good & 234 & 1.11 & $\begin{array}{l}\text { depend, depended, dependent, dependents, depending, depends, effect, } \\
\text { effective, effectiveness, effects, estimate, expert, experts, full, good, goods, } \\
\text { honorability, honors, just, respect, respected, respects, right, rights, safe, } \\
\text { security, skill, skillful, skilling, skills, well }\end{array}$ \\
\hline 10 & development & 241 & 0.98 & $\begin{array}{l}\text { develop, developed, developers, developing, development, developments, } \\
\text { develops, educate, education, exploited, get, gets, getting, growing, } \\
\text { modern, preparation, prepare, prepared, produce, produced, rise, } \\
\text { rises, train, trained, training, trainings, trains }\end{array}$ \\
\hline 12 & loan & 110 & 0.93 & lend, lending, lends, loan, loans, loans' \\
\hline 13 & roads & 105 & 0.92 & road, roads, roads', routes \\
\hline 14 & building & 158 & 0.88 & $\begin{array}{l}\text { build, building, buildings, construct, construction, constructions, } \\
\text { figures, form, forms, frame, make, makes, making, progress, } \\
\text { progresses }\end{array}$ \\
\hline 15 & foreign & 95 & 0.81 & foreign, outside \\
\hline 16 & Chinese & 88 & 0.77 & Chinese \\
\hline 17 & Cambodian & 85 & 0.75 & Cambodian, Cambodians \\
\hline 18 & impact & 88 & 0.73 & affect, affected, impact, impacted, impacts \\
\hline 19 & people & 82 & 0.71 & mass, people, peoples \\
\hline 20 & infrastructure & 93 & 0.70 & base, based, infrastructure, infrastructures \\
\hline 21 & one & 75 & 0.66 & one, ones \\
\hline
\end{tabular}




\section{Continued}

bring, brings, contribute, contributed, contributes, contribution, contributions, donated, donates, give, giving, lead, leading, leads, lend, lending, lends, part, parts, share, shared, shares, sharing

consequences, cut, cuts, cutting, effect, effective, effectiveness, effects, emerged, emergent, issue, issued, issues, number, numbers, outcome, outcomes, public, release, released, result, results, return, subject, supplied, supplies, supply, take, takes, taking, topic

clothes, commitment, committed, invest, invested, investment, investments, invests, place, places, put

external, externalize, figures, image, labor, labors, plan, project, projects, projects', proposed, see, seeing, stick, task, visual

condition, conditionalities, conditionality, conditions, price, prices, term, terms

applied, apply, applying, consumption, employ, employability, employed, employers, employment, exercise, exploited, function, functional, habits, purpose, purposes, role, roles, use, used, uses, using, victim

concern, concerned, concerning, concerns, interest, interested, interests, involved, involving, occupied

force, forced, forces, might, officers, power, powerful, powers, right, rights, strong, strongly, superpower, superpowers, tycoons

generated, generation, product, production, productions, productive, productivity, products, profit, profits, rich

$$
\text { military }
$$

extended, going, offer, offered, offerings, offers, proposed, provide, provided, providing

advantages, confident, confirm, deposited, favor, located, location, locations, officers, perspective, perspectives, place, places, position, positioned, positions, positive, post, profit, profits, put, set, sets, side, sides, situation, stance, status, view

attained, cause, causes, clear, constitution, cooked, create, created, creating, earn, earned, form, forms, gain, gained, gaining, gains, give, giving, hold, make, makes, making, name, named, preparation, prepare, prepared, produce, produced, reach, reached, realized, realizes, take, takes, taking, work, works

communication, communities, community, home, internal, international, nation, national, nations, subject

delivery, economy, keep, keeping, protect, protecting, protection, save, saves, saving, savings, write, writes, writing

bad, badly, big, expect, expectations, expected, give, giving, great, grown, heavy, liberate long 


\section{Continued}

\begin{tabular}{|c|c|c|c|c|}
\hline 47 & means & 95 & 0.38 & $\begin{array}{c}\text { agencies, agency, base, based, close, closed, closes, import, important, } \\
\text { imported, intend, mean, means, way, ways }\end{array}$ \\
\hline 48 & income & 45 & 0.38 & enter, income, incomes \\
\hline 49 & state & 94 & 0.38 & $\begin{array}{l}\text { declaration, declared, express, formal, position, positioned, positions, } \\
\text { positive, province, provinces, saying, state, states, submit, tell }\end{array}$ \\
\hline 50 & point & 102 & 0.38 & $\begin{array}{l}\text { aim, aimed, charge, charged, charges, charging, degree, detail, detailed, } \\
\text { direct, directed, directedly, directly, directs, indicated, indicator, item, } \\
\text { level, levels, peak, period, place, places, point, points, show, showing, } \\
\text { shows, stages, target, targeted, targets }\end{array}$ \\
\hline$\cdots \cdots$ & $\cdots \cdots$ & ...... & $\cdots \cdots$ & $\cdots \cdots$ \\
\hline 70 & political & 68 & 0.30 & $\begin{array}{l}\text { affairs, civil, culture, cultures, diplomatic, opinion, political, politically, } \\
\text { politics, respect, sentiment, smooth, thought, view }\end{array}$ \\
\hline$\cdots \cdots$ & $\cdots \cdots$ & $\cdots \cdots$ & $\cdots \cdots$ & $\cdots \cdots$ \\
\hline 997 & pooling & 1 & 0.01 & pooling \\
\hline 998 & poorer & 1 & 0.01 & poorer \\
\hline 999 & preah & 1 & 0.01 & preah \\
\hline \multirow[t]{2}{*}{1000} & prekadam & 1 & 0.01 & prekadam \\
\hline & & 16,871 & 97.86 & \\
\hline
\end{tabular}

Source: Author Analysis, Some Word Frequency Query is selected from 1000 out of 16871 words from data analysis by using Nvivo 10.

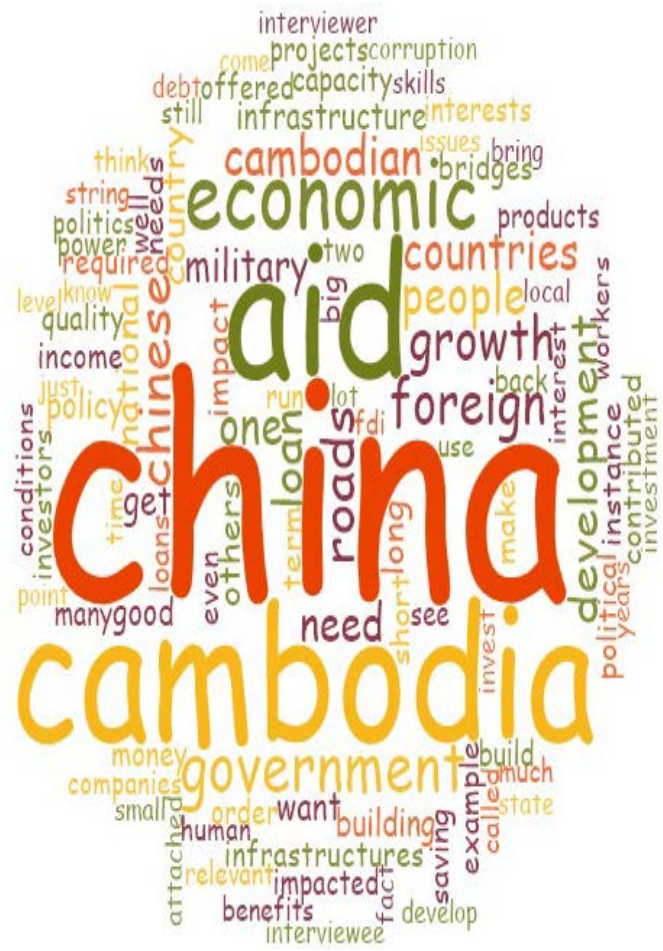

Figure 1. The picture is about the key words of word cloud, Chinese foreign aid, politics, and economic growth in Cambodia. 


\subsection{Chinese Foreign Aid as Grant in Economic Infrastructure and Social Infrastructure and Economic Growth}

China grant is offered to develop some government friendship infrastructures which are some buildings, bridges and roads. All participants were claimed that China grant to develop some buildings and bridges has strengthening in bilateral relations and has a little impact on short term economic growth. But Chinese grant to develop physical infrastructures has contributed in long term economic growth.

\subsection{Chinese Foreign Aid as Concessional Loan and Economic Growth}

First, China concessional loan is lent to Cambodia for economic infrastructure development. These physical economic infrastructures are bridges, roads, railway, irrigation systems and others. 83 percent of participants were endorsed that China loan as big capital inflows has contributed in short term economic growth and these economic infrastructures have impacted in long-term economic growth. Second, China grants and China concessional loan has in-directed impacted on foreign direct investment (FDI) by increasing investors because Cambodia has got good enough economic infrastructures has developed by Chinese financial assistance (grant and concessional loan) brought about billions of US dollars as capital inflows and created big employment to Cambodia. China aid has in-directed impact on FDI and has a significant contribution to short term and long-term economic growth.

\section{Discussion}

\subsection{Chinese Foreign Aid as Grant and Economic Growth}

China grant is offered to develop some government friendship infrastructures which are some buildings, bridges and roads. All participants were claimed that China grant to develop some buildings and bridges has strengthening in bilateral relations and has a little impact on short term economic growth. But Chinese grant to develop physical infrastructures has contributed in long term economic growth.

\subsection{Chinese Foreign Aid as Concessional Loan and Economic Growth}

China concessional loan is lent to Cambodia for economic infrastructure development. These physical economic infrastructures are bridges, roads, railway, irrigation systems and others. 83 percent of participants were endorsed that China loan as big capital inflows has contributed in short term economic growth and these economic infrastructures have impacted in long-term economic growth. Second, China grant and China concessional loan has in-directed impacted on foreign direct investment (FDI) by increasing investors because Cambodia has got good enough economic infrastructures has developed by Chinese financial 
assistance (grant and concessional loan) brought about billions of US dollars as capital inflows and created big employment to Cambodia. China aid has in-directed impact on FDI and has a significant contribution to short term and long-term economic growth.

\subsection{Chinese Foreign Aid as Military's Infrastructure Development and Economic Growth}

All participants were claimed that China aid as grant to training in soldiers, prevention of terrorism, human trafficking, crimes across borders, human resources development in military services, technical assistance in military, internal politics, military armaments, military infrastructures, military clothes and materials, trucks, weapons and other military armaments, trainings, military infrastructures, strengthening military forces, power and military development have impacted on national defense contributed economic growth. These findings were identified that are consistent with past researches, China was committed to offer an additional amount of $\$ 100$ million in military aid to Cambodia during another a visit of National Defense Minister Wei Fenghe of China. China and Cambodia have continued to strengthening in friendship with each other to grow stronger, it was evidence that China have offered additional grants amounting \$ 99.5 million to Cambodian military. National defense of Cambodia's spokesman told to the VOA while he was in an interview that defense officials were committed plans to spend the budget over the coming years, adding that the two countries were also agreed to continue their jointing military drills, commonly known as the Golden Dragon exercises for Cambodia and China military. In addition, Em, a political analyst averred that China-Cambodia relations were reached to an all-time high, partly due to a souring degree of relations with Western countries. He claimed that Cambodia looked carefully to keep and maintain relations with the United States and European Union, both major buyers of Cambodian garments and other products. Jointing military exercises with China have been conducted since 2016, while the Angkor Sentinel exercises previously held with the United States and Australia were cancelled [45].

These short of loans are aimed at building economic infrastructures such as roads, bridges, railways, seaports. This has been claimed repeatedly by Prime Minister Hun Sen China aid has a huge contribution to economic growth in Cambodia [46]. China aid has stimulus economic growth. Economic growth has been impacted by all infrastructure accessibility and technology [47]. China is invested in Cambodia was about $\$ 14$ billion that China has focused infrastructure, mine, agriculture, hydro-power grids and garment factory [48]. Based on the Ministry of Economy and Finance, 2017 is revealed that in terms of loans Cambodia has owed 3.9 billion to China (Po, 2017) [49]. China has offered loans for infrastructure development [38]. Upper middle countries were recognized the positive impact of aid flows and economic engagement on economic growth [50] [51]. 
In summary, China grant was offered to civil services and arm forces in human resources development and technical assistance, medical services volunteers and other interests of infrastructures have contributed in short term and long term on economic growth but not consistent with the past researches.

\subsection{Chinese Foreign Aid as All Transportation Infrastructure Developments and Economic Growth}

All participants were claimed that China grant to develop some buildings and bridges has strengthening in bilateral relations and has a little impact on short term and long term economic growth. However, Chinese grant to develop physical economic infrastructures has contributed in sustainable interests and long-term economic growth. The findings were identified that are consistent with past researches, Chinese foreign aid has impacted short term and long term on economic growth [52]. Increasing liberal trading was positive contribution in short run and long-run on economic growth. But foreign aid was positive effects on growth in short run. DFI was positively contributed on growth in long run. Foreign aid was only positive impact on growth in short run [32]. The findings indicate that in the short run and long run capital flows (FDI, aid, and external debt) have negative effects on economic growth [53]. Chinese foreign aid was to promote Impact of both trade openness and aid inflows on economic growth is positive and statistically significant in both short run and long run were the results identified. Chinese foreign aid as grant to develop friendship's buildings and bridges has strengthening bond and bilateral relations. The grant has a limited impact on short term economic growth. Other hand, Chinese grant to develop all physical infrastructures has contributed in sustainable interests in short term and long-term economic growth and as landmarks of meaningful China and relations. In summary, Chinese leaders are offered indirect aid through tourism industries, business infrastructures have contributed to economic growth via Chinese top leaders disseminated Chinese tourists to visit Cambodia. This is therefore, Chinese visitors have generated revenues that is contributed to Cambodian national interest and economic growth.

\subsection{Chinese Foreign Aid and Multilateral Aid Are Correlated to Economic Growth}

83 percent of participants were endorsed that China concessional loan is as a big capital inflow from China to Cambodia for development economic infrastructure in respect to develop buildings, bridges, roads, railways, irrigation systems and agricultural infrastructures, foreign direct investments, increasing on trading through accessibility of transportation and cost reduction of transportation, national interests have in-directed impacted on contributed in short-term and long-term economic growth. These findings were identified that are consistent with past researches, the correlation of foreign aid and economic growth have drawn attentions among researchers and policy maker since decades. The studies conducted by Papanek (1972), Dowling and Hiemenz (1982), Gupta and Is- 
lam (1983), Burside and Dollar (1997), Hansen and Tarp (2000), Dalgaard et al. (2004), Gomanee et al. (2005) and Karras (2006) found evidences that foreign aid positive impact on economic growth [52]. This is the same as above foreign aid has positively affected on economic growth in developing countries [54].

The studies were concluded that foreign financial assistance in relation to education, primary education, technical assistance, population growth, good governance, investment, economic and trade, economic infrastructures and social infrastructures development were statistically significant impacts and contribution on economic growth in short run and long run [9] [11] [12] and foreign aid is targeted to promote economic growth, improve public well-being, military capacity and humanitarian of allies infrastructures, promoting free market in former communist countries and economic growth [55]. However, China loan was one of the big sources that were contributed to economic growth.

\subsection{Chinese Foreign Aid to Economic Infrastructure Development Contribution to Short Run and Long Run on Economic Growth}

83 percent of participants claim that Chinese foreign aid as concessional loan is as the biggest capital inflow from China to Cambodia for development physical economic infrastructure and social infrastructure development in respect to develop buildings, bridges, roads, railways, irrigation systems, power grids and agricultural infrastructures have impacted on foreign direct investment, increasing on trading through accessibility of transportation and cost reduction of transportation, national interests have contributed in short-term and long-term economic growth. These findings are unique and consistent with the statements of the scholars [39] [40] that Chinese foreign aid on economic infrastructure developments contributes to economic growth in Cambodia.

\section{Conclusion and Recommendations for Future Researches}

China concessional loan is offered to develop physical economic infrastructures has contributed to short term and long-term economic growth. Chinese foreign aid to physical economic infrastructure development and economic growth in short run and log run. 83 percent of participants claim that Chinese foreign aid as concessional loan is as the biggest capital inflow from China to Cambodia for development physical economic infrastructure and social infrastructure development in respect to develop buildings, bridges, roads, railways, irrigation systems, power grids and agricultural infrastructures have impacted on foreign direct investment, increasing on trading through accessibility of transportation and cost reduction of transportation, national interests have contributed in short-term and long-term economic growth. Despite almost 20 percent concerns on the influx of China capital inflows.

This study suggests that China financial assistance to recipient countries need to be more be more justification on challenges on negatives impacts of China fi- 
nancial assistance of implications of China approaches or means to recipient countries. Major policy implications need to consider to make foreign aid increasing effectiveness and enhancing good governance on improving quality of economic infrastructures and economic growth.

\section{Conflicts of Interest}

The author declares no conflicts of interest regarding the publication of this paper.

\section{References}

[1] Open Development Cambodia, 08 December 2015. https://opendevelopmentcambodia.net/topics/international-relations

[2] Hout, S. and Nuch, R. (2016) The Roles of China's Aid to Cambodia's Socio-Economic Development. Cambodia Institute for Cooperation and Peace (CICP).

[3] Akins, M.E. (1981) United States Control over World Bank Group Decision-Making.

[4] Alesina, A. and Dollar, D. (2000) Who Gives Foreign Aid to Whom and Why? Journal of Economic Growth, 5, 33-63. https://doi.org/10.1023/A:1009874203400

[5] Kuziemko, I. and Werker, E. (2006) How Much Is a Seat on the Security Council Worth? Foreign Aid and Bribery at the United Nations. Journal of Political Econo$m y, 114,905-930$. https://doi.org/10.1086/507155

[6] Dreher, A., Sturm, J.-E. and Vreeland, J.R. (2009) Development Aid and International Politics: Does Membership on the UN Security Council Influence World Bank Decisions? Journal of Development Economics, 88, 1-18.

https://doi.org/10.1016/j.jdeveco.2008.02.003

[7] Ye, Q. (2017) China's Foreign Aid and Economic Growth: What Is the Effect of China's Foreign Aid and Economic Growth in Developing Countries? Erasmus University, Rotterdam.

[8] Zhang, J. (2016) Chinese Foreign Assistance, Explained.

[9] Burgos, S. and Ear, S. (2010) China's Strategic Interests in Cambodia: Influence and Resources. Asian Survey, 50, 615-639. https://doi.org/10.1525/as.2010.50.3.615

[10] Goldin, I. (2009) Aid, International. Princeton University Press, Princeton.

[11] Fashina, O.A., Asaleye, A.J., Ogunjobi, J.O. and Lawal, A.I. (2018) Foreign Aid, Human Capital and Economic Growth Nexus: Evidence from Nigeria. Journal of International Studies, 11, 104-117. https://doi.org/10.14254/2071-8330.2018/11-2/8

[12] Janjua, P.Z., Muhammad, M. and Usman, M. (2018) Impact of Project and Programme Aid on Economic Growth: A Cross Country Analysis. Pakistan Development Review, 57, 145-174. https://doi.org/10.30541/v57i2pp.145-174 https://ezproxy.flinders.edu.au:2073/docview/2235018684?accountid=10910

[13] Khalid, I. (2017) China's One Belt One Road Initiative: Towards Mutual Peace \& Development. Journal of Research of Society of Pakistan, 54, 1-20.

[14] Cheng, M. (2016b) Has Chinese Foreign Aid Contributed to Economic Growth in Africa? (10103729 M.P.P.), Georgetown University, Washington DC.

[15] Min, Z. (2016) The Rationale and Strategy behind the China's Foreign Aid towards Its Southern Neighbours. International Journal of Education and Social Sciences, 3 , 5. 
[16] Var, V. (2016) Cambodia's Strategic Relationship with China and the United States: Implications for Cambodia's Development Aid. European Academic Research, 4, 1712-1726.

[17] Arndt, C., Jones, S. and Tarp, F. (2015) Assessing Foreign Aid's Long-Run Contribution to Growth and Development. World Development, 69, 6-18. https://doi.org/10.1016/j.worlddev.2013.12.016

[18] Nowak, W. (2015) China's Development Aid Strategies. Chinese Business Review, 14, 201-209. https://doi.org/10.17265/1537-1506/2015.04.004

[19] Wang, H. and French, E. (2014) China in Global Economic Governance. Asian Economic Policy Review, 9, 254-271. https://doi.org/10.1111/aepr.12068

[20] Brückner, M. (2013) On the Simultaneity Problem in the Aid and Growth Debate. Journal of Applied Econometrics, 28, 126-150. https://doi.org/10.1002/jae.1259

[21] Clemens, M.A., Radelet, S., Bhavnani, R.R. and Bazzi, S. (2012) Counting Chickens When They Hatch: Timing and the Effects of Aid on Growth. The Economic Journal, 122, 590-617. https://doi.org/10.1111/j.1468-0297.2011.02482.x

[22] Akramov, K.T. (2012) Foreign Aid Allocation, Governance, and Economic Growth. University of Pennsylvania Press, Philadelphia. https://doi.org/10.9783/9780812207736

[23] Kislyakova, E. (2010) The Effectiveness of Foreign Aid: Empirical Essays. University of Surrey (United Kingdom), Ann Arbor, 226.

[24] Kaosar, A. and Idrees, M. (2010) Testing the Aid-Growth Nexus for South Asia. Applied Econometrics and International Development, 10, 213-222.

[25] Ekanayake, E.M. and Chatrna, D. (2007) The Effect of Foreign Aid on Economic Growth in Developing Countries. Journal of International Business and Cultural Studies, 3-11.

[26] Minoiu, C. and Reddy, S.G. (2010) Development Aid and Economic Growth: A Positive Long-Run Relation. The Quarterly Review of Economics and Finance, 50, 27-39.

[27] Xiao, L. (2010) The Effect of Foreign Aid on Economic Growth and Corruption in Developing Countries. Northeast Normal University, Changchun.

[28] Annen, K. and Kosempel, S. (2009) Foreign Aid, Donor Fragmentation, and Economic Growth. Federal Reserve Bank of St Louis, St. Louis.

https://ezproxy.flinders.edu.au https://doi.org/10.2202/1935-1690.1863

[29] Doucouliagos, H. and Paldam, M. (2008) Aid Effectiveness on Growth: A Meta Study. European Journal of Political Economy, 24, 1-24. https://doi.org/10.1016/j.ejpoleco.2007.06.002

[30] Headey, D. (2008) Geopolitics and the Effect of Foreign Aid on Economic Growth: 1970-2001. Journal of International Development, 20, 161-180.

https://doi.org/10.1002/jid.1395

[31] Doucouliagos, H. and Paldam, M. (2009) The Aid Effectiveness Literature: The Sad Results of 40 Years of Research. Journal of Economic Surveys, 23, 433-461. https://doi.org/10.1111/j.1467-6419.2008.00568.x

[32] Lin, T.-C. (1993) The Foreign Aid Policy of the People's Republic of China: A Theoretical Analysis. 9400653 Ph.D., Northern Illinois University, Ann Arbor. https://search.proquest.com/docview/304056397

[33] Ahmed, M.M. (2018) Foreign Capital Inflow and Economic Growth: A Case Study of Bangladesh. Cardiff Metropolitan University (United Kingdom), Ann Arbor, 1. 
[34] Urban, F., Siciliano, G., Sour, K., Lonn, P.D., Tan-Mullins, M. and Mang, G. (2015) South-South Technology Transfer of Low-Carbon Innovation: Large Chinese Hydropower Dams in Cambodia. Sustainable Development, 23, 232-244. https://doi.org/10.1002/sd.1590

[35] Pheakdey, H. (2013) Chinese Investment and Aid in Cambodia a Controversial Affair. In: Forum, E.A., Ed., Economics, Politics and Public Policy in East Asia and the Pacific.

[36] (2012) Interview: Cambodia, ASEAN Honor Closer Cooperation with China. Xinhua News Agency CEIS. Woodside.

[37] Lahiri, S. (2007) Theory and Practice of Foreign Aid. Frontiers of Economics and Globalization Vol. 1. https://doi.org/10.1016/S1574-8715(06)01027-X

[38] Brautigam, D. (2009) The Dragon's Gift: The Real Story of China in Africa. Oxford University Press, Oxford.

[39] Xiaosong, W. and Siyuan, T. (2020) Institutional Quality, Foreign Aid and Economic Growth in Recipient Countries. China Economist, 15, 68-83.

[40] Bhavan, T., Xu, C. and Zhong, C. (2011) Growth Effect of Foreign Aid and Volatility in South Asia. International Journal of Development Issues, 10, 204-213. https://doi.org/10.1108/14468951111165340

[41] Sekaran \& Bougie (2013) Methods for Business: A Skill Building Approach (5th Edition).

[42] Creswell, J.W. (2008) Educational Research Planning, Conducting, and Evaluating Quantitative and Qualitative Research. 3rd Edition, Pearson, Upper Saddle River.

[43] Palinkas, L.A., et al. (2015) Purposeful Sampling for Qualitative Data Collection and Analysis in Mixed Method Implementation Research. Administration and Policy in Mental Health and Mental Health Services Research, 42, 533-544. https://doi.org/10.1007/s10488-013-0528-y

[44] Gill, P., et al. (2008) Methods of Data Collection in Qualitative Research: Interviews and Focus Groups. British Dental Journal, 204, 291-295.

https://doi.org/10.1038/bdj.2008.192

[45] (2018) China's Pledges More Military Aid as Cambodia Prepares for Controversial Election: China to Extend US $\$ 100$ m Package to Southeast Asian Ally in Pledge That One Expert Says Shows an Increasing Reliance by Hun Sen on Beijing. South China Morning Post, Hong Kong.

[46] Pheakdey, H. (2012) Cambodia-China Relations: A Positive-Sum Game? Journal of Current Southeast Asian Affairs, 31, 57-85. https://doi.org/10.1177/186810341203100203

[47] Wolf, C. (2013) The Strategy behind China's Aid Expansion; between 2001 and 2011, China’s Pledged Foreign Aid Was \$671 Billion. Wall Street Journal (Online), New York.

[48] Sum, M. (2016) China to Align Asean Policy with Cambodia. Khmer Times. http://www.khmertimeskh.com/news/32729/china-to-align-asean-policy-with-cam $\underline{\text { bodia }}$

[49] Po, S. (2017) The Limited of China's Influence in Cambodia: A Soft Power. UC Occasional Paper Series, 1, 61-76.

[50] Harb, N. and Hall, S.G. (2019) Does Foreign Aid Play a Role in the Maintenance of Economic Growth? A Non-Linear Analysis. The Quarterly Review of Economics and Finance, 73, 192-204. https://doi.org/10.1016/j.qref.2018.12.002

[51] Po, S. and Primiano, C.B. (2020) An “Ironclad Friend": Explaining Cambodia's 
Bandwagoning Policy towards China. Journal of Current Southeast Asian Affairs, 39, 444-464. https://doi.org/10.1177/1868103420901879

[52] Sahoo, K. (2016) Foreign Aid and Economic Development: Empirical Evidence from Select South Asian Economies Department of Humanities and Social Sciences National Institute of Technology Rourkela. Doctor of Philosophy.

[53] Klobodu, E.K.M. and Adams, S. (2016) Capital Flows and Economic Growth in Ghana. Journal of African Business, 17, 291-307. https://doi.org/10.1080/15228916.2016.1169784

[54] Fayissa and Al-Kaisy (1999) Foreign Aid, FDI, Economic Freedom and Economic Growth in Asian Countries. Global Economy Journal, 11, Article ID: 1850231.

[55] Alhamad, M. (2018) The Effect of Foreign Aid on Poverty Reduction in Developing Countries. Morgan State University, Ann Arbor, 56. 